Article

\title{
Agricultural Practices Modulate the Beneficial Activity of Bacterial-Feeding Nematodes for Plant Growth and Nutrition: Evidence from an Original Intact Soil Core Technique
}

\author{
Jean Trap ${ }^{1, * \mathbb{D}}$, Mahafaka Patricia Ranoarisoa ${ }^{1}$, Sariaka Raharijaona ${ }^{2}$, Lilia Rabeharisoa $^{2}$, Claude Plassard ${ }^{1}$, \\ El Hassan Mayad ${ }^{3}$, Laetitia Bernard ${ }^{1}$, Thierry Becquer ${ }^{1}$ and Eric Blanchart ${ }^{1} \mathbb{D}$ \\ 1 Eco\&Sols, Institut Agro, Univ Montpellier, CIRAD, INRAE, IRD, 34060 Montpellier, France; \\ ranpatricia@yahoo.fr (M.P.R.); claude.plassard@inrae.fr (C.P.); laetitia.bernard@ird.fr (L.B.); \\ thierry.becquer@ird.fr (T.B.); eric.blanchart@ird.fr (E.B.) \\ 2 Laboratoire des Radio-Isotopes, University of Antananarivo, Antananarivo 101, Madagascar; \\ sasaharinaval@yahoo.fr (S.R.); rabeharisoa.lilia@gmail.com (L.R.) \\ 3 Laboratory of Biotechnology and Valorization of Natural Resources, Faculty of Sciences, Agadir, \\ Ibn Zohr University, Agadir 80000, Morocco; e.mayad@uiz.ac.ma \\ * Correspondence: jean.trap@ird.fr
}

Citation: Trap, J.; Ranoarisoa, M.P.; Raharijaona, S.; Rabeharisoa, L.; Plassard, C.; Mayad, E.H.; Bernard, L.; Becquer, T.; Blanchart, E. Agricultural Practices Modulate the Beneficial Activity of Bacterial-Feeding

Nematodes for Plant Growth and Nutrition: Evidence from an Original Intact Soil Core Technique. Sustainability 2021, 13, 7181. https:// doi.org/10.3390/su13137181

Academic Editor: Silvia Tabacchioni

Received: 23 May 2021

Accepted: 24 June 2021

Published: 26 June 2021

Publisher's Note: MDPI stays neutral with regard to jurisdictional claims in published maps and institutional affiliations.

Copyright: (c) 2021 by the authors. Licensee MDPI, Basel, Switzerland. This article is an open access article distributed under the terms and conditions of the Creative Commons Attribution (CC BY) license (https:/ / creativecommons.org/licenses/by/ $4.0 /)$.

\begin{abstract}
Free-living nematodes have beneficial effects on plant growth and nutrition. Exploring how agricultural practices modulate these beneficial effects is still challenging. A study was conducted in Ferralsols from Madagascar from one unmanaged grassland and 16 upland rainfed rice fields, representative of different agricultural practices: rotation, agroforestry and monoculture. Intact soil cores in plastic cylinders were sampled in the field to assess the effects of agricultural practices on changes in plant growth and nutrition induced by the presence of bacterial-feeding nematodes. The soil cores were fumigated to kill the nematodes and moistened with a filtered fresh soil suspension containing only microbial cells. A rice seed was introduced in the core, which was then incubated under natural climatic conditions for 40 days with or without inoculation of the bacterial-feeding nematode Acrobeloides sp. The inoculation of the nematodes induced lower, similar or higher plant biomass and nutrient content in comparison to the control according to the agricultural practices. Positive effects of Acrobeloides sp. on plant functions were frequent in soil cores sampled from fields with high plant diversity, especially from agroforestry systems. The intact soil core technique appears to be a robust means of mimicking field conditions and constitutes a promising tool to assess effects on soil processes of the ecological intensification of agricultural practices.
\end{abstract}

Keywords: sustainable agriculture; soil fertility; plant nutrition; Oryza sativa; Acrobeloides sp.; soil microbial loop; agroforestry; Ferralsols

\section{Introduction}

Nematodes are cosmopolite and abundant animals [1]. In the soil, they contribute to key functions [2], such as organic matter decomposition [3], nutrient cycling [4], stimulation of microbial activity [5,6] and plant nutrition and growth [7]. Free-living nematodes are known to greatly improve nitrogen $(\mathrm{N})$ and phosphorus $(\mathrm{P})$ availability for plants through the soil microbial loop [8-10]. Because $\mathrm{N}$ and $\mathrm{P}$ are the main macronutrients limiting crop productivity in many terrestrial ecosystems [11,12], improving nutrient availability for crops by promoting the beneficial activities of free-living nematodes is a promising technique for sustainable agriculture.

Identifying agricultural practices that promote the beneficial effects of free-living nematodes, beyond measurements of field nematode abundance and composition, is however still challenging. To date, various methodological tools have been used to study the effects of bacterial-feeding organisms on nutrient availability [9,13-16], from the simplest ones, appropriate for disentangling mechanisms, to more complex devices that attempt to 
mimic field conditions. The simplest experimental models were liquid cultures that could be a soil suspension or a mineral saline solution [14,17-19]. For instance, Griffiths [18] showed, using liquid culture, that $\mathrm{N}$ mineralization was greater when bacterial-feeding nematodes (Rhabditis sp.) and protozoan ciliates (Colpoda steinii) were combined than with C. steinii alone. Some studies used sieved soil without plants [17,20-23]. More recent work introduced plants in their assays, either with autoclaved sand or a soil-sand mixture [24], or using a humus-sand mixture [25], or sometimes with agarose [16,26]. For instance, Clarholm [10] showed that the presence of protists (from a soil suspension) increased wheat biomass and $\mathrm{N}$ content in plant tissues by $78 \%$ after six weeks of incubation. Similar patterns have been observed for plant $P$ content [27]. These designs allowed a good control of experimental systems in which the form and the amounts of each nutrient are well known $[7,10,28,29]$.

Whatever the experimental design, quantifying the beneficial activity of soil bacterivores for soil and plant functions is a technical challenge [30]. Most of the studies inoculate soil organisms in disturbed soils, usually $2 \mathrm{~mm}$-sieved soils. Sieving the soil is indeed required to homogenize the substrate, to kill bacterial-feeding organisms and to avoid confounding effects in controlled experiments. It is still however questionable whether these methods reflect actual field conditions and whether they alter the effect of bacterialfeeding organisms on plant growth and nutrition. More recently, Gebremikael et al. [15] used soil cores in plastic tubes with sieved soil compacted to the bulk density found in the field to assess the effects of nematodes on plant functions in conditions close to the field. Fauna were killed by applying gamma irradiation with a dose proven to eradicate nematodes and other fauna without significantly altering the native microbial community. This approach is technically relevant, even if the soil is sieved, but remains less effective for the monitoring and screening of the beneficial activity of bacterivores in the field. In addition, this method is difficult to apply in less developed countries where use of gamma irradiation is not feasible.

It appears important however to be able to measure to what extent a given agricultural practice influences the beneficial activity of soil nematodes for the growth and nutrition of crop plants. For example, by providing fertilizers to the soil, the farmer strongly influences the abundance and composition of nematode communities [31] but also the nitrogen mineralizing activity of bacterial-feeding nematodes [8]. Practices that can alter soil porosity can also influence nematode dispersal and nematode-root interactions [32]. The beneficial activities of nematodes on plants can also be influenced by the presence of other soil organisms with which they interact in trophic and non-trophic manners [33-36]. Thus, the effects of free-living soil nematodes on plant growth are likely to vary depending on how agricultural practices alter the chemical, physical and biological properties of the soil nematode habitat.

In the highlands of Madagascar, the soils of hills cropped with rainfed rice are acidic nutrient-depleted Ferralsols [37]. Poor smallholder farmers do not have access to expensive mineral fertilizers. In these conditions, an effective intensification of the soil functions involved in improved soil nutrient availability is required. In this study, we aimed at testing a new method based on intact, undisturbed soil cores from various rainfed rice fields to assess the potential beneficial activity of the bacterial-feeding nematode Acrobeloides sp. for rice growth and nutrition. This method was developed to limit disturbance. We first hypothesized that the presence of Acrobeloides sp. in the rhizosphere of rice has a positive effect on plant growth and nutrition as reported in the literature [38]. However, the size of the beneficial effect of the nematode on plant nutrition and growth is likely to vary depending on the management of the field from which the soil cores are sampled.

\section{Materials and Methods}

\subsection{Selection of Upland Rice Fields}

The study was carried out in upland rainfed rice (Oryza sativa) systems, in farmers' fields. A total of 17 fields were selected in Madagascar in the region of Itasy (Figure S1 
in Supplementary Materials). We selected only upland rainfed rice fields and a natural grassland as a reference non-cultivated area. Rice was grown as a monoculture, as an intercrop or in rotation (Table 1). For each field, we collected agronomic data (e.g., crop history, crop management, soil management). The 17 fields were gathered in five agronomic groups depending on crop diversity: (i) agroforestry (F1, F2, F4, F5, F6 and F7), (ii) rotation (F3, F8, F10, F12 and F13), (iii) rice monoculture (F11, F14, F15 and F16), (iv) fallow (F9) and (v) grassland (F17). The F3 field, which presents intercropping, was classified as in rotation. These fields were thus representative of the cropping practices developed by farmers in the highlands of Madagascar, i.e., association with legumes or trees, organic inputs, fertilization and soil tillage (Table 1). The soils from the fields were all ferrallitic soils. Nine fields were sampled in 2016, and eight were sampled in 2017.

Table 1. Selected agronomical characteristics of the 17 sampled fields from Madagascar classified into the five categories, i.e., grassland, fallow, monoculture, rotation and agroforestry. SY and PY indicate sampling and previous year, respectively.

\begin{tabular}{|c|c|c|c|c|c|c|}
\hline \multirow[t]{2}{*}{ Practices } & \multirow[t]{2}{*}{ Fields } & \multicolumn{2}{|c|}{ Crops } & \multirow{2}{*}{$\begin{array}{c}\text { Fertilization } \\
\text { SY }\end{array}$} & \multirow{2}{*}{$\begin{array}{c}\text { Tillage } \\
\text { SY }\end{array}$} & \multirow[t]{2}{*}{ SY } \\
\hline & & $\begin{array}{l}\text { Sampling Year } \\
\text { (SY) }\end{array}$ & $\begin{array}{l}\text { Previous Year } \\
\text { (PY) }\end{array}$ & & & \\
\hline Grassland & F17 & Grassland & Grassland & No & No & 2016 \\
\hline Fallow & F9 & $\begin{array}{l}\text { Fallow with } \\
\text { eucalypt }\end{array}$ & $\begin{array}{l}\text { Rice with } \\
\text { eucalypt }\end{array}$ & No & No & 2016 \\
\hline \multirow[t]{4}{*}{ Monoculture } & F16 & Rice & Grassland & $\begin{array}{l}\text { Manure with ashes and } \\
\text { rice chaff }\end{array}$ & Yes & 2016 \\
\hline & F15 & Rice & Grassland & Compost & Yes & 2016 \\
\hline & F14 & Rice & Grassland & Manure & Yes & 2016 \\
\hline & F11 & Rice & Rice & Compost with ashes & Yes & 2017 \\
\hline \multirow[t]{5}{*}{ Rotation } & F13 & Rice & Sweet potato & $\begin{array}{l}\text { Ashes with crop } \\
\text { residues }\end{array}$ & Yes & 2017 \\
\hline & F12 & Rice & Jugo bean & Compost with ashes & Yes & 2017 \\
\hline & F10 & $\begin{array}{l}\text { Sweet potato } \\
\text { (Ipomoea batatas) }\end{array}$ & French beans & Rice straw & Yes & 2016 \\
\hline & F8 & $\begin{array}{l}\text { Maise with Jugo } \\
\text { bean (Vigna } \\
\text { subterranea) }\end{array}$ & Rice & Compost & Yes & 2016 \\
\hline & F3 & $\begin{array}{c}\text { Rice with } \\
\text { groundnut } \\
\text { (Arachis hypogaea) }\end{array}$ & $\begin{array}{c}\text { Soybean (Glycine } \\
\max )\end{array}$ & $\begin{array}{l}\text { Compost with manure } \\
\text { and crop residues }\end{array}$ & Yes & 2017 \\
\hline \multirow[t]{6}{*}{ Agroforestry } & F7 & $\begin{array}{l}\text { Rice with } \\
\text { eucalypt }\end{array}$ & Eucalypt & Compost with manure & Yes & 2017 \\
\hline & F6 & $\begin{array}{l}\text { Rice with banana } \\
\text { (Musa sp.) }\end{array}$ & Banana with Taro & Compost & Yes & 2017 \\
\hline & F5 & $\begin{array}{l}\text { Rice with } \\
\text { groundnut and } \\
\text { coffee trees }\end{array}$ & $\begin{array}{l}\text { Coffee tree with } \\
\text { Taro (Colocasia } \\
\text { esculenta) }\end{array}$ & Compost & Yes & 2017 \\
\hline & $\mathrm{F} 4$ & $\begin{array}{l}\text { Rice with coffee } \\
(C . \text { arabica }) \text { trees }\end{array}$ & $\begin{array}{l}\text { French beans } \\
\text { (Phaseolus } \\
\text { vulgaris) with } \\
\text { coffee tree }\end{array}$ & Crop residues & Yes & 2017 \\
\hline & $\mathrm{F} 2$ & $\begin{array}{l}\text { Rice with } \\
\text { Stylosanthes } \\
\text { guianensis and }\end{array}$ & $\begin{array}{l}\text { Stylosanthes with } \\
\text { Tephrosia }\end{array}$ & No & No & 2016 \\
\hline & $\mathrm{F} 1$ & $\begin{array}{c}\text { Rice } \$ \text { with } \\
\text { Eucalyptus robusta } \\
\text { and maize (Zea } \\
\text { mays) }\end{array}$ & $\begin{array}{l}\text { Grassland with } \\
\text { eucalypt }\end{array}$ & $\begin{array}{l}\text { Compost with green } \\
\text { manure }\end{array}$ & No & 2016 \\
\hline
\end{tabular}

\$ Oryza sativa cultivar B22. 


\subsection{Soil Sampling}

For each campaign, seven days before the beginning of the assay, three intact soil cores (top $10 \mathrm{~cm}$ depth) were sampled in the middle of each field, near a plant, with PVC cylinders (Figure 1). The PVC cylinders ( $4.5 \mathrm{~cm}$ diameter and $12 \mathrm{~cm}$ height) were open from the top and from the bottom and drilled on the sides ( 12 holes $\sim 5 \mathrm{~mm}$ in diameter throughout the height of the tube) to facilitate air exchange between the soil inside the cylinder and the atmosphere. These three soil cores were labeled " $\mathrm{T}_{-7}$-cores". A composite sample made of 5 soil samples, also in the $0-10 \mathrm{~cm}$ depth, was collected for the analysis of soil abiotic parameters. This composite soil sample was collected in the middle of each field. The soil cores and the composite sample were carefully transported to the laboratory. One week later, 10 soil cores, designated " $\mathrm{T}_{0}$-cores", were sampled per field in the same area using identical PVC cylinders. They were used to conduct the assay. Soil bulk density was determined in the field using a soil core sampler, which was pushed into the soil at $10 \mathrm{~cm}$ depth. The soil was sieved at $2 \mathrm{~mm}$ and oven dried at $105^{\circ} \mathrm{C}$ for $24 \mathrm{~h}$ in the laboratory.

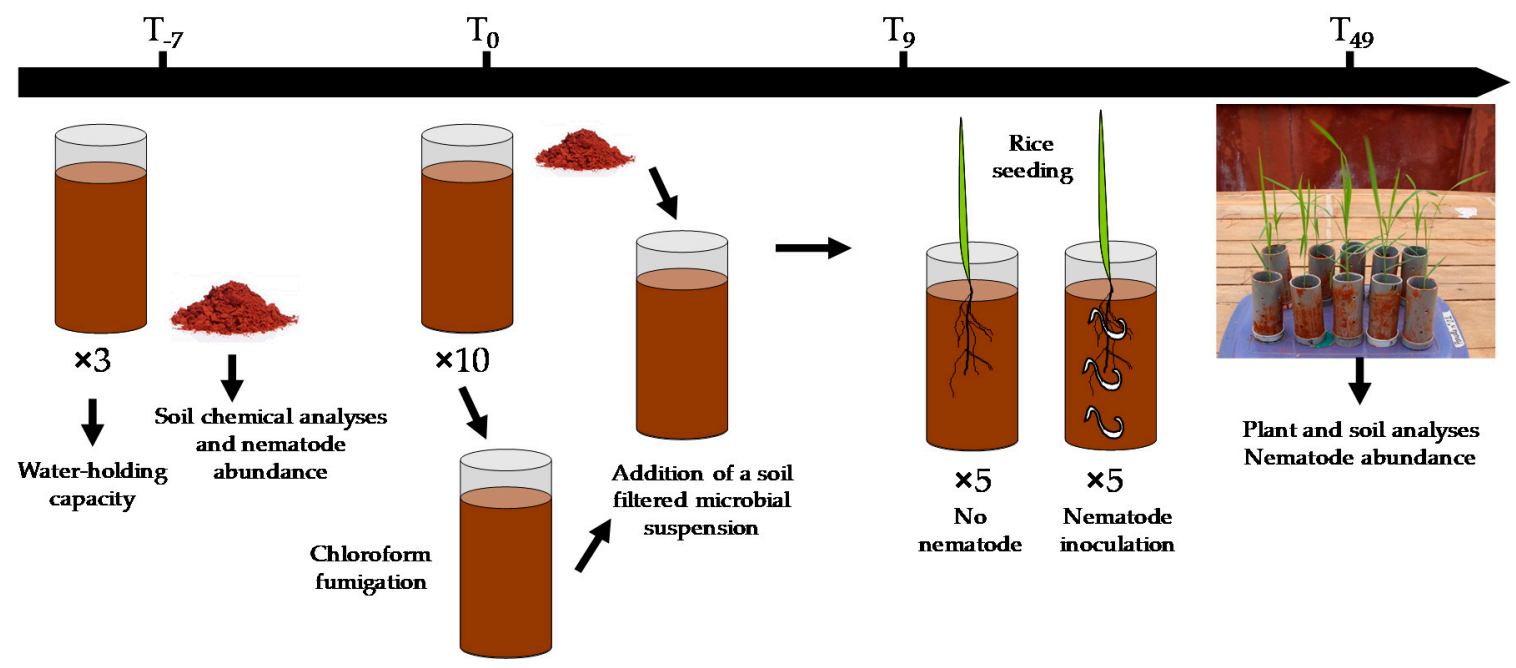

Figure 1. Chronogram of the implementation of the intact soil core technique to assess the effect of Acrobeloides on plant nutrition and growth. " $\mathrm{T}$ " indicates time in days (see text).

\subsection{Soil Analyses}

The three " $\mathrm{T}_{-7}$-cores" were used to assess the soil water-holding capacity (WHC) within the cylinder (Figure 1). The soil cores were saturated with water in a basin for $2 \mathrm{~h}$ and then placed on a sand tray for $1 \mathrm{~h}$. Soil moisture was determined after oven drying an aliquot $(20 \mathrm{~g})$ at $105^{\circ} \mathrm{C}$ for $24 \mathrm{~h}$. The composite soil sample was air-dried until constant weight and stored at room temperature for further analyses. Three sub-samples were randomly taken to perform the physicochemical measurements. Soil $\mathrm{pH}$ was measured in water $\left(\mathrm{pH} \mathrm{H}_{2} \mathrm{O}\right)$ (1:2.5 mass ratio) after 30 min shaking on a back-and-forth agitator. Particle size distribution was assessed for five fractions: clay $(0-2 \mu \mathrm{m})$, fine silt $(2-20 \mu \mathrm{m})$, coarse silt $(20-50 \mu \mathrm{m})$, fine sand $(50-200 \mu \mathrm{m})$ and coarse sand $(200-2000 \mu \mathrm{m})$. Cation exchange capacity (CEC) was measured after saturation with a cobaltihexamine chloride solution. CEC was estimated by measuring the Cobalt remaining in solution by flame atomic absorption spectrometry (iCE 3000 Series, Thermo Scientific, Japan). We also measured three exchangeable cations: $\mathrm{Ca}^{2+}, \mathrm{Mg}^{2+}$ and $\mathrm{K}^{+}$. Soil organic carbon (C) and $\mathrm{N}$ contents were assessed using Walkley and Black [39] and Kjeldahl [40] methods, respectively. Total phosphorus (P) content was determined after perchloric acid digestion [41]. Labile inorganic $\mathrm{P}$ in water was extracted with an ion-exchange resin filled with bicarbonate (0.5M) [42]. P concentration was analyzed by colorimetry with malachite green [43]. Nematodes were extracted using a modified Seinhorst [44] elutriation method from $250 \mathrm{~g}$ moist soil. The number of free-living nematodes was counted in $5 \mathrm{~mL}$ of the final volume of water collected. 


\subsection{Biological Materials}

We used the upland rice cultivar B22, which was introduced in Madagascar in the early 1980s. This cultivar is widely used by farmers in Itasy [45,46]. Its optimal altitude of cropping is between 700 to $1200 \mathrm{~m}$. Monoxenic populations of nematodes (Acrobeloides sp.), isolated from Lazaina $\left(18^{\circ} 46^{\prime} 5559^{\circ} \mathrm{S}, 47^{\circ} 32^{\prime} 463^{\circ} \mathrm{N}, 1274\right.$ m.a.s.l. Madagascar), were grown on E. coli following the procedure described by Irshad et al. [26]. Acrobeloides is a ubiquitous genus that dominates bacterivorous nematode communities in upland rice systems in the Malagasy highlands [47]. The nematodes were collected by rinsing a Petri dish with sterile water. The nematode suspension was centrifuged at $4000 \mathrm{rpm}$ for $10 \mathrm{~min}$ and washed with sterile water. The number of individuals in the washed nematode suspension was counted under a binocular stereoscope. Half of this suspension was sampled, and the volume was adjusted to provide an expected number of nematodes per $\mathrm{mL}$ (solution $\mathrm{A}$ ). The remaining half was filtered at $8 \mu \mathrm{m}$ (solution B) and used for the control. The absence of nematodes (including eggs) in solution B was confirmed.

\subsection{Soil Core Preparation for the Assay}

The first step aimed to kill the nematodes. The $\mathrm{T}_{0}$-cores were moistened with distilled water at $50 \%$ of their water-holding capacity and fumigated with chloroform vapor for $2 \mathrm{~h}$ (Figure 1). We repeated the $2 \mathrm{~h}$ chloroform fumigation after $24 \mathrm{~h}$. Because fumigation with chloroform vapor induces a lysis of microbial cell membranes [48], a microbial suspension was prepared for each field by vigorously mixing $100 \mathrm{~g}$ of non-fumigated soil in 400 $\mathrm{mL}$ of distilled sterile water for $10 \mathrm{~min}$. The soil from the suspension was decanted by sedimentation for $1 \mathrm{~h}$, and the suspension was filtered at $8 \mu \mathrm{m}$ in order to eliminate freeliving nematodes. Two days after the second sampling, the soil cores were moistened at $100 \%$ of their WHC with a fresh microbial suspension, i.e., each soil core was re-inoculated with its own microbial bacterial community. The soil cores were incubated for seven days in the dark at $24^{\circ} \mathrm{C}$.

\subsection{Experimental Design and Setup}

The soil cores were split into two groups (5 cores per group): (i) without the nematode Acrobeloides sp. corresponding to the control $(-\mathrm{N})$ and (ii) with the nematodes $(+\mathrm{N})$. For each field, five replicates were thus set up for each nematode treatment. Seven days after the addition of the microbial suspension, one rice seed was sown in each soil core (Figure 1). For the $+\mathrm{N}$ treatment, 10 individuals of Acrobeloides per gram of dry soil were added by adding $10 \mathrm{~mL}$ of solution $\mathrm{A}$. For the $-\mathrm{N}$ treatment, $10 \mathrm{~mL}$ of solution $\mathrm{B}$ was added to the core. The soil cores were then incubated in the experimental station of the Laboratoire des Radio Isotopes (University of Antananarivo, Madagascar) on benches located outside. Soil water content was adjusted twice per day for optimal nematode and plant growth. For the first campaign (February to April 2016), the temperature was $17-25^{\circ} \mathrm{C}$, the mean air humidity was $91 \%$ and the cloud coverage was $51 \%$. For the second campaign (April and May 2017), the temperature was $19-23{ }^{\circ} \mathrm{C}$, the air humidity was $74 \%$ and the cloud coverage was 25\% (Ampandrianomby Weather Center, Antananarivo, Madagascar).

\subsection{Soil and Plant Analyses at the End of the Assay}

After 40 days of growth, shoots and roots of each plant were collected separately. The roots were gently washed with distilled water to remove the adhering soil. Dry root and shoot biomasses were determined after oven drying at $60^{\circ} \mathrm{C}$ for $48 \mathrm{~h}$. Total C and $\mathrm{N}$ contents in plant tissues were determined using a CHNS/O elemental analyzer. Total $\mathrm{P}$ content in plant tissues was determined after crushing and mineralization of plant tissues with nitric acid 65\% (US EPA Method 3051). P concentration was analyzed in the mineralized solution by colorimetry with the vanado-molybdate method. A soil aliquot of $150 \mathrm{~g}$ from each core was used to extract the nematodes using the same method described earlier. The total nematode density was determined using a stereoscope. 


\subsection{Statistical Analyses}

To explore the variability in soil properties among the fields, we conducted a principal component analysis using soil abiotic data [49]. For each field and nematode treatment, the mean and standard deviation $(n=5)$ of each variable were computed. We then calculated the effect size of the nematode treatment on plant growth and nutrition with Cohen's d (1988) and the following formula (1):

$$
\mathrm{d}=(\mathrm{M} 1-\mathrm{M} 2) /(\text { pooled SD) }
$$

where M1 is the mean of each variable for the $+\mathrm{N}$ treatment, M2 is the mean of each variable for the $-\mathrm{N}$ treatment and pooled $\mathrm{SD}$, the square root of the common variance of the populations. Cohen's d effect size can be described as being "very small, small, medium, large, very large or huge" according to the magnitude of $\mathrm{d}$. The $\mathrm{d}$ value can thus be used as a proxy of the beneficial activity of Acrobeloides sp. To determine if the value of the mean effect size was significantly different from zero, we performed a Student test (statistical significance set at 0.05). One-Way ANOVA and post hoc Tukey HSD tests were used to test for significant differences among the fields in final soil nematode abundance. The normality of model residuals was verified using the Shapiro test. Finally, partial least squares regression (PLS-R) models were used to evaluate the relationships between the agronomic and soil abiotic variables and the effect of Acrobeloides sp. on rice growth and nutrition $[50,51]$. Cohen's $d$ was used as the response variable. Model strength was assessed by the proportion of variance in the dependent variable that can be predicted by the model $\left(Q^{2}\right)$. At the $5 \%$ level, the test is considered significant when $Q^{2}$ exceeds a critical value of 0.097 [50]. The variable importance of projection (VIP) reflects the relative influence of each explanatory variable in the construction of the model. Explanatory variables with VIP $>1$ are the most relevant and significant for explaining the dependent variable. We used three PLS-R models to evaluate the relationships between the agronomic and soil abiotic variables as predictors of the effect of Acrobeloides sp. on plant total biomass (first model), plant total nitrogen (second model) and plant total phosphorus (third model). For each model, we first included all the explanatory variables. Then, a second model was achieved with only the explanatory variables with VIP $>1$ in order to improve the quality of the models. All tests were done with R, except those with the PLS-R models, which were performed using TANAGRA 1.4.5 [52].

\section{Results}

\subsection{Soil Properties of the Selected Fields}

All fields exhibited soil properties typical of Ferralsols, with low organic matter contents and acidic $\mathrm{pH} \mathrm{H}_{2} \mathrm{O}$ (Table $\mathrm{S} 1$ in Supplementary Materials). On average, the soils contained 26 g. $\mathrm{kg}^{-1}$ total C, $2.1 \mathrm{~g} . \mathrm{kg}^{-1}$ total $\mathrm{N}, 0.72 \mathrm{cmol}^{+} . \mathrm{kg}^{-1} \mathrm{Ca}$ and $0.26 \mathrm{cmol}+. \mathrm{kg}^{-1}$ $\mathrm{Mg}$. The mean $\mathrm{pH} \mathrm{H}_{2} \mathrm{O}$ was 5.04 . The sampled fields were also characterized by a low $\mathrm{C} / \mathrm{N}$ ratio (12) and high $\mathrm{C} / \mathrm{P}$ ratio (31). However, although all the soils were Ferralsols, we observed a large variation for some soil parameters among the fields with a coefficient of variation $(\mathrm{CV})$ higher than $15 \%$. Olsen $\mathrm{P}(\mathrm{CV}=83 \%)$ and $\mathrm{K}$ contents $(\mathrm{CV}=71 \%)$ were the soil parameters with the highest variations. The principal component analysis performed on soil parameters reveals the large dispersion on the first two axes, explaining $44.6 \%$ of the total inertia, of soil properties (Figure 2). The first axis (relative inertia $=22.7 \%$ ) opposes fields with high (coarse and fine) sand content, bulk density and C/P ratio (negative scores) to fields with high $\mathrm{P}, \mathrm{N}, \mathrm{K}$ and clay contents (positive scores) (Figure 2B). The second axis (relative inertia $=21.9 \%$ ) opposes fields with high $\mathrm{Ca}, \mathrm{Mg}$, Pi and CEC contents (positive scores) to fields with high total $\mathrm{C}$ and $\mathrm{N}$, fine silt contents, $\mathrm{Ca} / \mathrm{Mg}$ ratio and $\mathrm{pH}_{\mathrm{KCl}}$. 
A
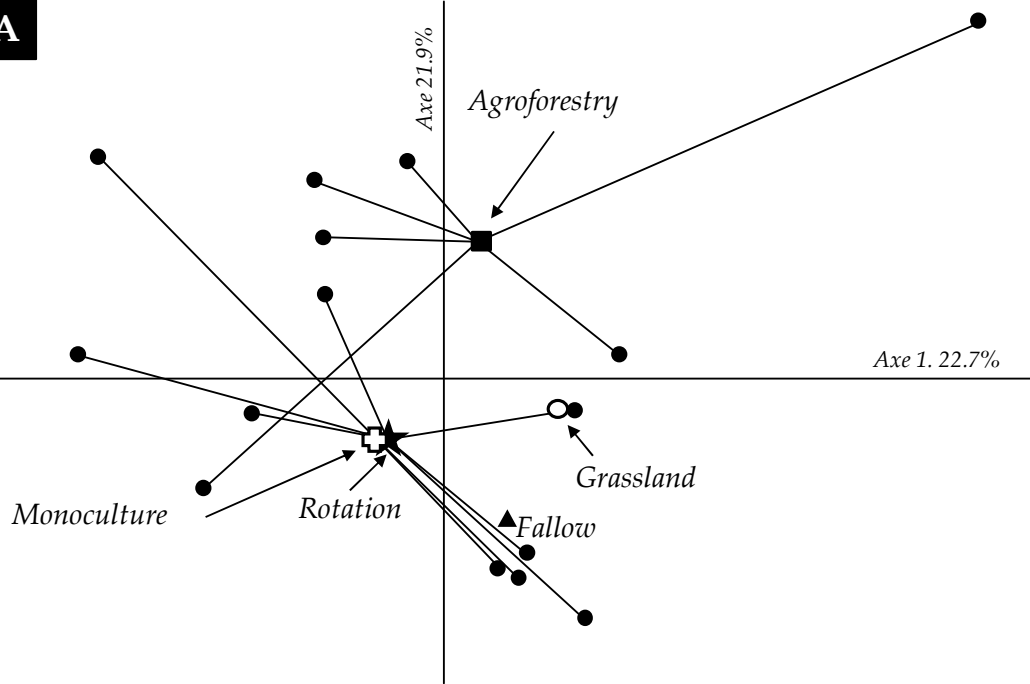

B

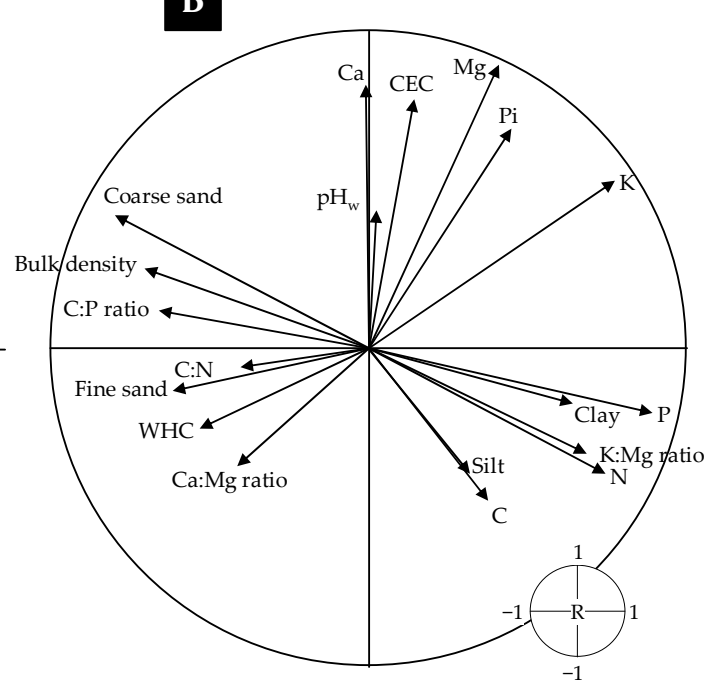

Figure 2. Principal component analysis performed on soil parameters. (A) Factorial plan of the first two axes with black square, black star, empty cross, black triangle and empty circle as barycenters for "agroforestry", "rotation", "monoculture", "fallow" and "grassland", respectively. Black circles are the fields. The first two axes explained $22.7 \%$ and $21.9 \%$ of the total variance. (B) Circle of correlations for the first two axes. WHC: water-holding capacity; C: carbon; N: nitrogen; P: phosphorus; K: potassium; Ca: calcium; Mg: magnesium; CEC: cation exchange capacity; Pi: inorganic P.

\subsection{Final Soil Nematode Abundance}

Forty days after inoculation, we did not observe nematodes in the controls. However, the final abundance of Acrobeloides sp. in the inoculated soil cores varied between fields (Figure 3). Nematode abundance was the highest in F5 (around 110 individuals per g dry soil) and the lowest in grassland ( 3 individuals per $g$ dry soil).

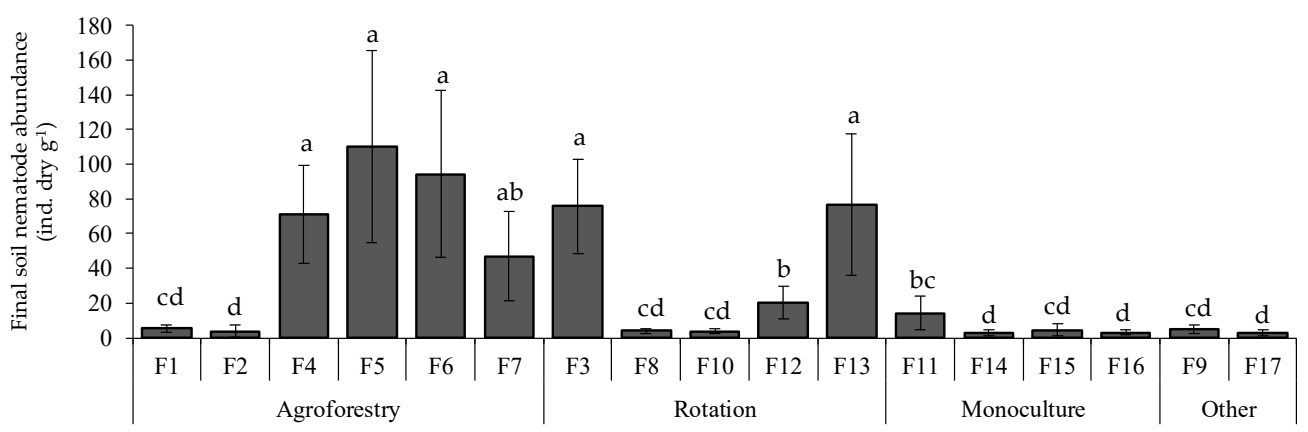

Figure 3. Final nematode abundance in the inoculated soil cores after 40 days of plant growth. Whiskers correspond to standard deviation. Different letters $(a, b$ and $c)$ indicate significant differences between the fields according to Tukey HSD test $(p$ value $<0.05)$

\subsection{Effects of Bacterial-Feeding Nematodes on Plant Growth}

The inoculation of Acrobeloides sp. in the soil cores induced negative, neutral or positive effects on plant growth and nutrition (Figure 4). Nematode inoculation induced significantly higher shoot biomass than the control in 10 of the 17 fields with an average positive effect of $35 \%$ more than the control (Figure $4 \mathrm{~A}$ ). 


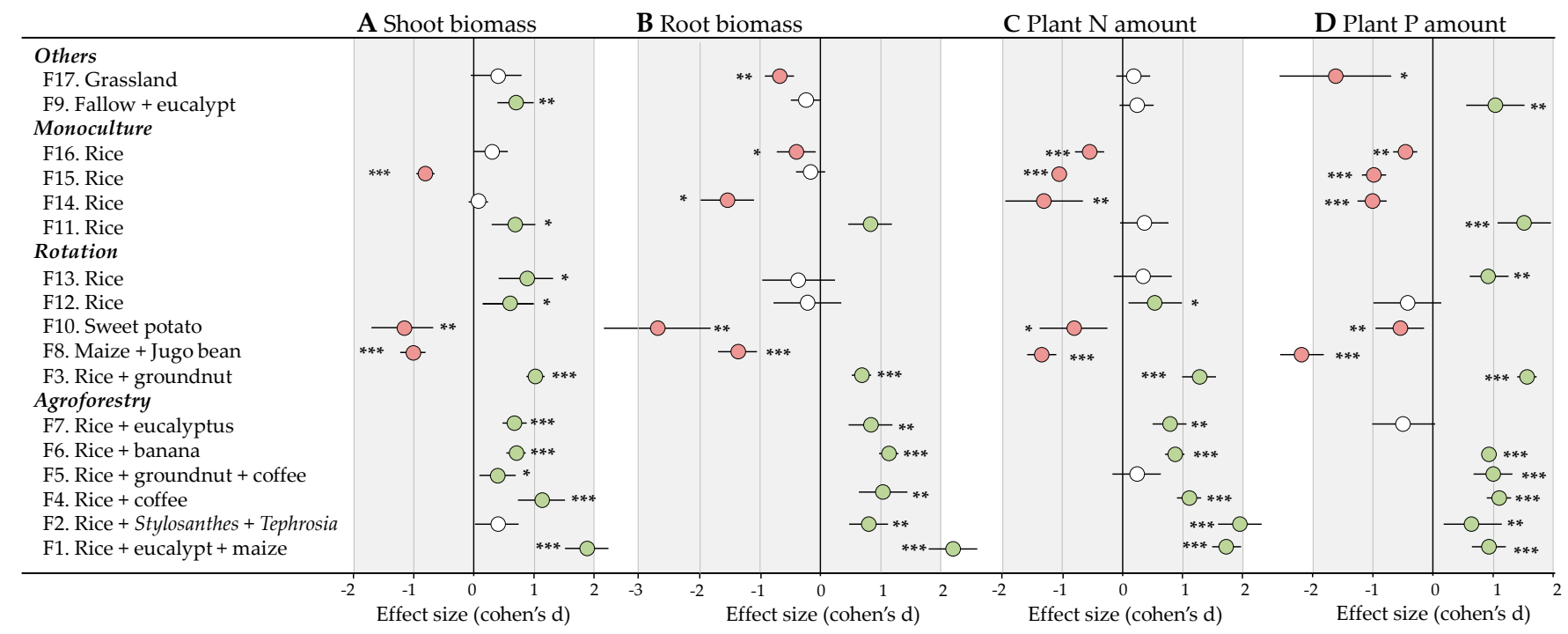

Figure 4. Mean effect size (Cohen's d) of the inoculation of Acrobeloides sp. for (A) shoot biomass, (B) root biomass and (C) total $\mathrm{N}$ and (D) total $\mathrm{P}$ amount in plant tissue after 40 days of growth in intact soil cores originating from different agricultural fields. Red, white and green circles indicate negative, neutral (not significantly different from 0 ) and positive mean effect size, respectively ( $p$ value $<0.05^{*},<0.01^{* *},<0.001^{* * *}$ ). Horizontal bars correspond to $95 \%$ confidence interval.

More precisely, we recorded the most positive effect sizes of Acrobeloides sp. on shoot biomass in soil cores sampled from fields characterized by the presence of trees. The effect size for F1 was very large $(\mathrm{d}=1.9)$, whereas the effect size for F5 was small $(\mathrm{d}=0.4)$. On the other hand, the inoculation of nematodes had a negative effect on shoot biomass for three of the 17 fields, with a mean negative effect of around 19\%. These fields were characterized by the presence of legumes and mostly corresponded to rotated crops. The patterns of variation for root biomass were close to those found for shoot biomass (Figure 4B). Nematode inoculation induced significantly higher and lower root biomasses than the control in seven and five fields, respectively. Again, the highest positive effects were found for the soil cores sampled in agroforestry fields, while fields F10 (sweet potato) and F8 (maize with jugo bean) exhibited the highest negative effect sizes.

\subsection{Effects of Bacterial-Feeding Nematodes on Plant Nutrition}

The bacterial-feeding nematode increased rice total $\mathrm{N}$ uptake in seven fields with an average positive effect of $39 \%$ compared to the control (Figure $4 \mathrm{C}$ ). The effect size was very large for F2 $(\mathrm{d}=1.94)$ and medium for $\mathrm{F} 12(\mathrm{~d}=0.52)$. The effect of the bacterivorous nematodes was significantly negative for five of the 17 fields with a mean negative effect of around 19\%. More precisely, nematodes significantly decreased rice total $\mathrm{N}$ uptake, with medium to large effect sizes, for the microcosms from fields under a rice monoculture system (F14, F15 and F16) and in the rotated crops (F8 and F10).

Rice total P uptake increased following nematode inoculation for nine of the 17 fields with an average positive effect of $62 \%$ more than the control (Figure 4D). The effect size was very large for F3 $(d=1.5)$ and medium for F2 $(d=0.6)$. The nematodes had a significantly negative effect for six of the 17 fields resulting in an average of 30\% less total P uptake than the control. The bacterivorous nematodes significantly decreased rice total P uptake for the microcosms from fields under a rice monoculture system (F14, F15 and F16) and in the rotated crops (F8 and F10).

\subsection{Agronomic and Soil Drivers of the Beneficial Activity of Bacterial-Feeding Nematodes for Plant Growth and Nutrition}

According to the PLS regression models, both agronomic and soil abiotic properties were significantly related to the effects of bacterial-feeding nematodes on plant growth and nutrition (Figure 5). The effect size of nematodes on plant growth was well explained 
by agronomic and soil data, with an $\mathrm{R}^{2}$ of 0.66 (quality of fit) and a $\mathrm{Q}^{2}$ of 0.34 (predictive quality). The slope (positive or negative) indicates the sign of the relationship between the predictors and the response variable. The presence of trees and rice in the field the year we sampled the soil and soil $\mathrm{pH}$ (positive slope) were the most important predictors. We also observed lower, but still high, variable importance in projection (VIP) values for soil $\mathrm{Mg}$ content, soil $\mathrm{K} / \mathrm{Mg}$ ratio, coarse sand content, $\mathrm{Ca} / \mathrm{Mg}$ and soil CEC (Figure $5 \mathrm{~A}$ ). Plant $\mathrm{N}$ nutrition after the inoculation of Acrobeloides sp. was the best model with an $\mathrm{R}^{2}$ of 0.94 and $\mathrm{Q}^{2}$ of 0.79 (Figure $5 \mathrm{~B}$ ). The predictors were mostly the presence of trees, the soil $\mathrm{Mg}$ and $\mathrm{Ca}$ contents and the soil $\mathrm{pH} \mathrm{H}_{2} \mathrm{O}$. Lower VIP values $(\sim 0.7-0.8)$ were observed for the soil C and $\mathrm{N}$ contents, the soil $\mathrm{K} / \mathrm{Mg}$ ratio, the presence of rice or rotated crops at the sampling date and coarse sand content (Figure $5 B)$. Plant $P$ nutrition was well explained $\left(R^{2}=0.66\right.$, $\mathrm{Q}^{2}=0.49$ ) by soil total $\mathrm{C}$ and $\mathrm{N}$ contents (negative slopes), the rotated crops at sampling date and soil Ca content (positive slopes, Figure 5C). We also found high VIP values for the soil $\mathrm{K} / \mathrm{Mg}$ ratio, the presence of rice, soil $\mathrm{Mg}$ content and coarse sand content, $\mathrm{pH}$ and the presence of trees (Figure 5C).

(A) Plant biomass

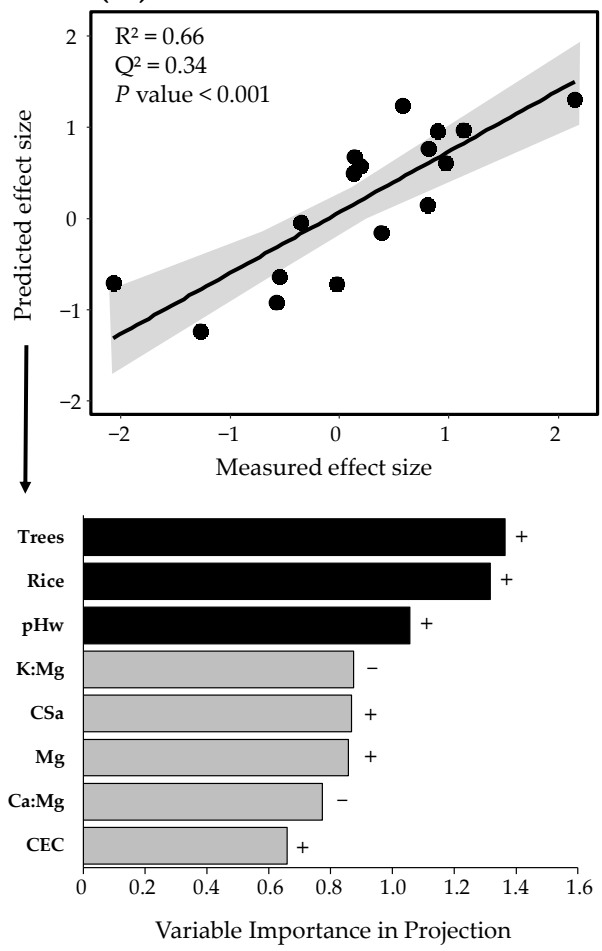

(B) Plant $\mathrm{N}$ amount
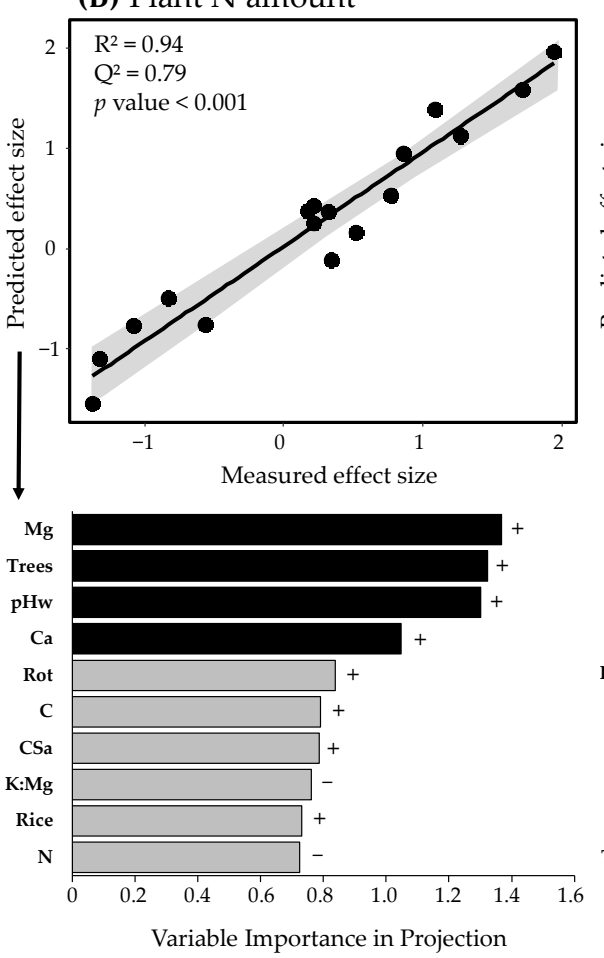

(C) Plant P amount
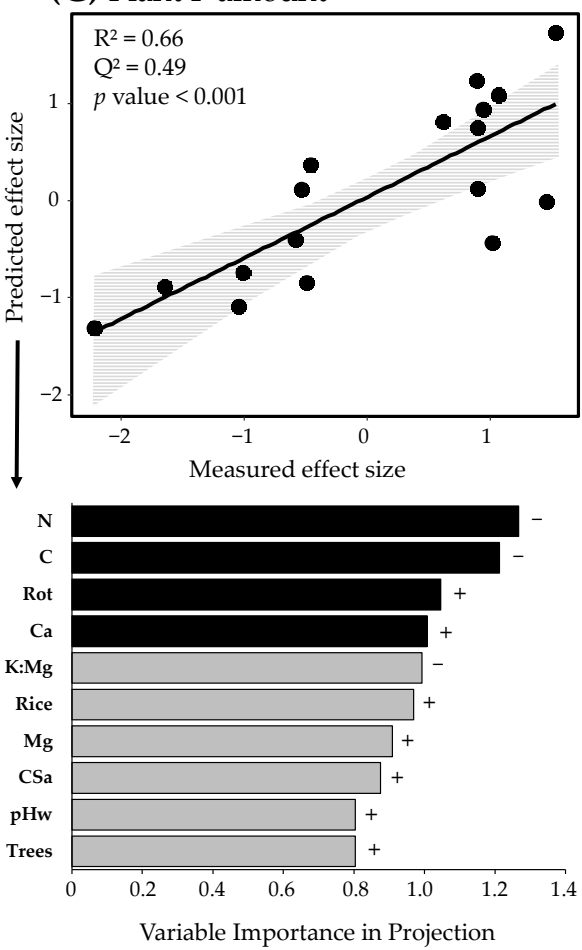

Figure 5. Partial least squares regression between agronomic and soil abiotic properties as explanatory variables and the effect size of the inoculation of Acrobeloides sp. for (A) plant biomass, (B) plant N amount and (C) plant P amount as response variables. Black circles are fields. Grey area corresponds to $95 \%$ confidence interval. "Trees" = presence of trees; "Rice" = rice as the crop at soil sampling date; "Rot" = rotated crops at the soil sampling date; "pHw" = soil water $\mathrm{pH}$; "CSa" = the percentage in coarse sand; " $\mathrm{C}$ " = total soil $\mathrm{C}$ content; " $\mathrm{N}$ " = total soil $\mathrm{N}$ content; "Ca" = soil Ca content; " $\mathrm{Mg}$ " = soil Mg content; " $\mathrm{Ca} / \mathrm{Mg}$ " = soil $\mathrm{Ca} / \mathrm{Mg}$ ratio; " $\mathrm{K} / \mathrm{Mg}$ " = soil $\mathrm{K} / \mathrm{Mg}$ ratio.

\section{Discussion}

\subsection{Diversity of Practices in Upland Rainfed Rice Systems}

We aimed at sampling fields with contrasting agricultural practices within the same cropping system, i.e., upland rainfed rice in high altitude tropical conditions, to test the effect of nematode inoculation in various agronomic conditions but within the same pedoclimatic context. We obtained a large panel of land and soil management practices within the same area and soil type. Principal component analysis is a relevant global visualization tool to summarize data set variance in low-dimensional space. The PCA 
allowed us to determine which soil properties best explained the total variance. The PCA performed on the soil parameters showed a wide dispersion in some soil abiotic parameters, even if all the fields were on Ferralsols. We observed a significant textural gradient not associated with cropping systems but related to soil total P content. Unsurprisingly, high $\mathrm{P}$ content in soil was associated with high clay content, in line with the high $\mathrm{P}$ sorption ability of clay [53]. The presence of trees was related to higher $\mathrm{Ca}, \mathrm{Mg}$ and $\mathrm{K}$ contents and soil $\mathrm{pH}$ as already observed in the literature [54]. We can thus conclude that our final field sampling fits well the criteria we defined initially.

\subsection{Variable Effects of Bacterial-Feeding Nematodes on Plant Growth and Nutrition}

Using an original intact soil core technique, we observed variable effects of the inoculation of the nematode Acrobeloides sp. on rice growth and nutrition. We observed significant positive and negative effects of the nematode on rice biomass in $50 \%$ and $23 \%$ of all the agronomic situations, respectively. The mean overall effects of Acrobeloides sp. on rice shoot and root biomass were $+19 \%$ and $+5 \%$, respectively. In a meta-analysis, Trap et al. [38] reported larger effects of bacterivores (nematodes and protists) on plant growth. They showed that bacterivores significantly increased shoot and root biomass with an average positive effect of $27 \%$ and $21 \%$, respectively, in comparison to the control. They mostly reported positive or neutral effects of bacterivores on plant growth. Similarly, in our study Acrobeloides sp. had either significant positive (47\% of the fields) or negative (32\% of the fields) effects on rice nutrition. The mean overall effects of Acrobeloides sp. on total plant $\mathrm{N}$ amount and $\mathrm{P}$ amount were around $+13 \%$ and $+21 \%$, respectively. Again, the meta-analysis conducted by Trap et al. (2016) showed greater overall bacterivore effects on the total plant $\mathrm{N}$ and $\mathrm{P}$ amounts in shoots and roots. The authors found that bacterivores increased shoot total $\mathrm{N}$ amount, root total $\mathrm{N}$ amount, shoot total $\mathrm{P}$ amount and root total $\mathrm{P}$ amount by $59 \%, 28 \%, 38 \%$ and $55 \%$ compared to the control, respectively. They reported very few negative effects on plant total $\mathrm{N}$ amount (only $3 \%$ of their observations).

We supposed that the use of intact soil cores should better allow the conservation of soil properties and differences in soil functioning between fields. Conversely, soil sampling, sieving, homogenization before filling the microcosms and other technical procedures must certainly converge towards similar soil situations limiting the differences between plots. Effect variance is indeed larger in our study, with more negative and null effect sizes, while the use of sieved soil, agar or liquid culture results in more homogeneous experimental conditions, likely to promote fewer variable patterns. The negative effects of the nematodes on plant growth and nutrition are more difficult to explain. However, the B22 rice cultivar is known to attract nematodes to a lesser extent than other cultivars [55]. It is possible that in specific soil conditions, the presence of the nematodes in high density close to the plant roots caused high rhizodeposition rates as observed by Sundin et al. [56] in comparison with plants without nematode inoculation. This excess of carbon loss may not be compensated by higher nutrient availability following nematode inoculation in comparison to the control [10], resulting in a net carbon loss and thus a lower final plant biomass. This hypothesis could be tested by measuring root exudation rate in the presence and absence of the nematode in various soil conditions. Nevertheless, in this case, the causes behind an absence in soil nutrient availability increase remain to be elucidated. To conclude, our method revealed that (1) the effect of bacterial-feeding nematodes on plant growth and nutrition may be more variable than expected from the literature according to environmental conditions, and (2) agricultural practices can modify the effect size of the beneficial activity of nematodes for plant growth and nutrition.

\subsection{Soil Drivers of the Beneficial Activity of Bacterial-Feeding Nematodes for Plant Growth and Nutrition}

The PLS models showed that soil $\mathrm{pH}$ was one of the best predictors of the effect of Acrobeloides sp. on plant growth and nutrition, especially N (Figure 5). More precisely, the effects of Acrobeloides sp. on plant growth and nutrition increased with increasing $\mathrm{pH}$ $\mathrm{H} 2 \mathrm{O}$. Soil pH is a well-known regulatory factor of soil nutrient availability [57]. Nutrients 
released by bacterivores can be absorbed by plants, re-immobilized within the microbial biomass or adsorbed to soil constituents according to the $\mathrm{pH}[8,58]$. Ferralsols are characterized by high contents of $\mathrm{Al}$ and Fe oxides able to precipitate inorganic $\mathrm{P}$ as minerals such as variscite $\left(\mathrm{AlPO}_{4} \cdot 2 \mathrm{H}_{2} \mathrm{O}\right)$ and strengite $\left(\mathrm{FePO}_{4} \cdot 2 \mathrm{H}_{2} \mathrm{O}\right)$, whose solubility increases with $\mathrm{pH}$ [59]. On the other hand, free Al concentration, and thus Al toxicity, decrease dramatically at $\mathrm{pH} 5.0$ [60]. We thus expected greater effects of bacterial-feeding nematodes on nutrient availability for soil $\mathrm{pH}$ values above 5.5-6, i.e., improving nutrient availability, especially inorganic $\mathrm{P}$, and reducing $\mathrm{Al}$ toxicity for rice.

We also found that the effect of Acrobeloides sp. on plant total $\mathrm{N}$ and $\mathrm{P}$ amount increased with increasing values of soil $\mathrm{Mg}$ and $\mathrm{Ca}$ content. A nutrient-omission trial conducted on Ferralsols collected from the same region showed high $\mathrm{Mg}$ and $\mathrm{Ca}$ deficiencies for rice and revealed a N-P-Ca-Mg co-limitation [37]. Furthermore, $\mathrm{Mg}$ is known to be a crucial element for the uptake of $\mathrm{N}$, especially nitrate [61]. It is thus possible that the increase in $\mathrm{N}$ and $\mathrm{P}$ availability caused by nematodes was more pronounced when $\mathrm{Mg}$ and $\mathrm{Ca}$ limitations were reduced. In contrast to the two previous models, the effect of nematodes on plant $\mathrm{P}$ nutrition was mostly explained by soil $\mathrm{C}$ and $\mathrm{N}$ contents, i.e., the effects of Acrobeloides sp. on plant total $\mathrm{P}$ amount increased with decreasing values of soil total $\mathrm{N}$ and $\mathrm{C}$. Because soil $\mathrm{C}$ is a limiting factor of microbial growth and activity, it is possible that a large number of $\mathrm{P}$ ions released by the bacterial-feeding nematodes were rapidly re-immobilized within the microbial biomass.

An interesting observation is that, despite high variations in final abundance of soil nematodes among the fields, this variable was not selected by the PLS model to explain the effect sizes. We thus concluded that the beneficial activity of nematodes for plant growth and nutrition was not related to nematode abundance. We noted that the final abundance of nematodes was higher in soil from the second campaign. An important soil parameter explaining nematode survival rates is the soil texture [62]. The soil particle size distribution of the fields sampled during the second campaign was coarser in comparison to the first one: clay $-21 \%$, fine silt $-17 \%$, coarse silt $+6 \%$, fine sand $+14 \%$ and coarse sand $+83 \%$. As shown by Jiang et al. [63], the average number of total nematodes increases with increasing aggregate size. It is thus possible that the final abundance of Acrobeloides sp. was related to changes in soil texture during the two campaigns. We exclude the effect of variable climate between the two campaigns, even if the soil cores were not incubated in a greenhouse. In both campaigns, the temperature reached the temperature niche breadth for Acrobeloides sp. ranging from 15 to $30^{\circ} \mathrm{C}$ [64], and soil moisture was monitored and corrected every day. To conclude, our PLS models revealed that agricultural practices may affect the beneficial activity of nematodes for plant nutrition and growth mostly by changing soil $\mathrm{pH}$ and cation ( $\mathrm{Ca}, \mathrm{Mg}$ and $\mathrm{K}$ ) contents but also total $\mathrm{C}$ and $\mathrm{N}$ contents.

\subsection{Agronomic Drivers of the Beneficial Activity of Bacterial-Feeding Nematodes for Plant Growth and Nutrition}

The PLS models revealed that Acrobeloides sp. mostly increased plant growth and total $\mathrm{N}$ amount in the microcosms from fields under agroforestry. We do not have precise elements to explain this pattern, and we can only speculate on certain mechanisms. Because soil bulk density was not a significant predictor in the PLS models, we can exclude the hypothesis that tree roots might improve nematode dispersal rate within the soil cores by increasing soil porosity and creating macropores. In contrast, as discussed earlier, soil Ca, $\mathrm{K}$ and Mg contents were good predictors; Pardon et al. [54] showed that the presence of trees increases soil nutrient content, resulting from the input of leaf litter or from deeper soil layers [65]. We also observed a high positive association between agroforestry and $\mathrm{Ca}, \mathrm{K}$ and $\mathrm{Mg}$ contents on the PCA (Figure 2). It is thus possible that the soil solution and microbial biomass nutrient contents near the tree roots are improved. It would be informative (i) to investigate spatial variation in soil carbon, nutrient, microbial biomass and nematodes within agroforestry fields according to tree distance and (ii) to conduct similar nematode assay with soil core sampling at various distances from the trees. 
We also found that rotation (the rotated crop) was a good predictor for the effect of Acrobeloides on plant total $\mathrm{P}$ amount. The precise quantity and type of fertilizers used by the farmers depend on the type of crop. The addition of crop residues stimulated bacterial growth by increasing the availability of labile carbon derived during initial phases of litter decomposition [30]. Thus, higher quantities of nutrients are stored in the microbial biomass, potentially unlocked by the activity of the bacterivores. To conclude, plant diversity in the field, and especially the presence of trees, was a key practice that affected the beneficial activity of nematodes for plant nutrition and growth.

\section{Conclusions: Limits and Perspectives}

The new method based on intact soil cores proposed in this study appears relevant and robust to test the effect of the bacterial-feeding nematode Acrobeloides sp. on rice growth and nutrition. Using this method, we were able to assess the effect of agricultural practices on the soil microbial loop driven by Acrobeloides sp. Indeed, a main finding of our study is the variable effect of the bacterial-feeding nematode Acrobeloides sp. on plant growth and function according to agricultural practices. We thus believe that driving the beneficial activity of free-living nematodes by appropriate agricultural practices is feasible. Agricultural practices based on improved plant diversity were highly correlated with beneficial activity of the nematodes. Furthermore, higher values in soil pH, and cation contents were associated with positive effect sizes of the nematode on plant growth and function. The nematode assay was time-consuming and required specific materials and skills. We quickly reached the maximum number of fields to investigate per year due to technical constraints. This is the reason why only 17 fields were investigated (170 soil cores) and why we split the samples in two campaigns. In this study, we did not measure the bacterial community structure or biomass, although it may explain the effects of nematodes on plants. It is likely that practices influence this microbial community with possible consequences on the effects of nematodes on rice. It would therefore be interesting to measure this aspect with a view to improving our understanding of the determination of the microbial loop. Finally, the identification of indicators of the beneficial activity of free-living nematodes based on rapid and cheap soil parameters will be a promising way to increase our ability to monitor the ecological intensification of agricultural practices.

Supplementary Materials: The following are available online at https:/ /www.mdpi.com/article/10 $.3390 /$ su13137181/s1. Figure S1. Localization of the fields in Madagascar. Table S1. Raw data of soil properties for each field.

Author Contributions: Conceptualization, J.T.; Methodology, J.T. and C.P.; data acquisition, M.P.R., S.R. and J.T.; formal analysis, M.P.R. and J.T.; writing-original draft preparation, M.P.R. and J.T.; writing-review and editing, all authors (J.T., M.P.R., S.R., L.R., E.H.M., L.B., T.B., E.B., C.P.); project administration, J.T.; funding acquisition, J.T. All authors have read and agreed to the published version of the manuscript.

Funding: This research was funded by the project "INDICE" (Agropolis Fondation, France) awarded to J.T. and was supported by the African Union, under reference AURG II-1-075-2016.

Institutional Review Board Statement: Not applicable.

Informed Consent Statement: Not applicable.

Data Availability Statement: The data presented in this study are available on request from the corresponding author.

Acknowledgments: We thank A.H.D. Razafimahafaly, H.M. Ralalason and M. Rakotondramanana for their technical help. We thank C. Marsden for proofreading the article and for improving the English.

Conflicts of Interest: The authors declare no conflict of interest. 


\section{References}

1. $\quad$ van den Hoogen, J.; Geisen, S.; Routh, D.; Ferris, H.; Traunspurger, W.; Wardle, D.A.; De Goede, R.G.; Adams, B.J.; Ahmad, W.; Andriuzzi, W.S.; et al. Soil nematode abundance and functional group composition at a global scale. Nature 2019, 572, 194-198. [CrossRef]

2. Wilschut, R.A.; Geisen, S. Nematodes as Drivers of Plant Performance in Natural Systems. Trends Plant Sci. 2020, $26,237-247$. [CrossRef]

3. Freckman, D.W. Bacterivorous nematodes and organic-matter decomposition. Agric. Ecosyst. Environ. 1988, $24,195-217$. [CrossRef]

4. Ferris, H. Contribution of nematodes to the structure and function of the soil food web. J. Nematol. 2010, 42, 63. [PubMed]

5. Blanc, C.; Sy, M.; Djigal, D.; Brauman, A.; Normand, P.; Villenave, C. Nutrition on bacteria by bacterial-feeding nematodes and consequences on the structure of soil bacterial community. Eur. J. Soil Biol. 2006, 42, S70-S78. [CrossRef]

6. Djigal, D.; Baudoin, E.; Philippot, L.; Brauman, A.; Villenave, C. Shifts in size, genetic structure and activity of the soil denitrifier community by nematode grazing. Eur. J. Soil Biol. 2010, 46, 112-118. [CrossRef]

7. Ingham, R.E.; Trofymow, J.; Ingham, E.R.; Coleman, D.C. Interactions of bacteria, fungi, and their nematode grazers: Effects on nutrient cycling and plant growth. Ecol. Monogr. 1985, 55, 119-140. [CrossRef]

8. Ferris, H.; Venette, R.C.; van der Meulen, H.R.; Lau, S.S. Nitrogen mineralization by bacterial-feeding nematodes: Verification and measurement. Plant Soil 1998, 203, 159-171. [CrossRef]

9. Ranoarisoa, M.P.; Morel, C.; Andriamananjaraa, A.; Jourdan, C.; Bernard, L.; Becquer, T.; Rabeharisoa, L.; Rahajaharilazaa, K.; Plassard, C.; Blanchard, E.; et al. Effects of a bacterivorous nematode on rice ${ }^{32} \mathrm{P}$ uptake and root architecture in a high P-sorbing ferrallitic soil. Soil Biol. Biochem. 2018, 122, 39-49. [CrossRef]

10. Clarholm, M. Interactions of bacteria, protozoa and plants leading to mineralization of soil-nitrogen. Soil Biol. Biochem. 1985, 17, 181-187. [CrossRef]

11. Holford, I.C.R. Soil phosphorus: Its measurement, and its uptake by plants. Aust. J. Soil Res. 1997, 35, 227-239. [CrossRef]

12. Vitousek, P.M.; Porder, S.; Houlton, B.Z.; Chadwick, O.A. Terrestrial phosphorus limitation: Mechanisms, implications, and nitrogen-phosphorus interactions. Ecol. Appl. 2010, 20, 5-15. [CrossRef] [PubMed]

13. Coleman, D.C.; Cole, C.V.; Anderson, R.V.; Blaha, M.; Campion, M.K.; Clarholm, M.; Elliott, E.T.; Hunt, H.W.; Shaefer, B.; Sinclair, J. An analysis of rhizosphere-saprophage interactions in terrestrial ecosystems. Ecol. Bull. 1977, 25, $299-309$.

14. Darbyshire, J.F.; Davidson, M.S.; Chapman, S.J.; Ritchie, S. Excretion of nitrogen and phosphorus by the soil Ciliate Colpoda steinii when fed the soil bacterium Arthrobacter sp. Soil Biol. Biochem. 1994, 26, 1193-1199. [CrossRef]

15. Gebremikael, M.T.; Buchan, D.; De Neve, S. Quantifying the influences of free-living nematodes on soil nitrogen and microbial biomass dynamics in bare and planted microcosms. Soil Biol. Biochem. 2014, 70, 131-141. [CrossRef]

16. Irshad, U.; Brauman, A.; Villenave, C.; Plassard, C. Phosphorus acquisition from phytate depends on efficient bacterial grazing, irrespective of the mycorrhizal status of Pinus Pinaster. Plant Soil 2012, 358, 148-161. [CrossRef]

17. Griffiths, B.S. Enhanced nitrification in the presence of bacteriophagous protozoa. Soil Biol. Biochem. 1989, $21,1045-1051$. [CrossRef]

18. Griffiths, B.S. Mineralization of nitrogen and phosphorus by mixed cultures of the Ciliate protozoan Colpoda steinii, the nematode Rhabditis sp and the bacterium Pseudomonas Fluoresc. Soil Biol. Biochem. 1986, 18, 637-641. [CrossRef]

19. Taylor, W.D. The effect of grazing by a ciliated protozoan on phosphorus limitation of heterotrophic bacteria in batch culture. J. Protozool. 1986, 33, 47-52. [CrossRef]

20. Rønn, R.M.; Griffiths, B.S.; Young, I.M. Protozoa, nematodes and N-mineralization across a prescribed soil textural gradient. Pedobiologia 2001, 45, 481-495. [CrossRef]

21. Woods, L.; Cole, C.; Elliott, E.; Anderson, R.; Coleman, D. Nitrogen transformations in soil as affected by bacterial-microfaunal interactions. Soil Biol. Biochem. 1982, 14, 93-98. [CrossRef]

22. Cole, C.V.; Elliott, E.T.; Hunt, H.W.; Coleman, D.C. Trophic interactions in soils as they affect energy and nutrient dynamics. Phosphorus transformations. Microb. Ecol. 1978, 4, 381-387. [CrossRef]

23. Coleman, D.C.; Anderson, R.V.; Cole, C.V.; Elliott, E.T.; Woods, L.; Campion, M.K. Trophic interactions in soils as they affect energy and nutrient dynamics. Flows of metabolic and biomass carbon. Microb. Ecol. 1978, 4, 373-380. [CrossRef]

24. Jentschke, G.; Bonkowski, M.; Godbold, D.L.; Scheu, S. Soil protozoa and forest tree growth-Non-nutritional effects and interaction with mycorrhizae. Biol. Fertil. Soils 1995, 20, 263-269. [CrossRef]

25. Baath, E.; Lohm, U.; Lundgren, B.; Rosswall, T.; Soderstrom, B.; Sohlenius, B. Impact of microbial-feeding animals on total soil activity and nitrogen dynamics-A soil microcosm experiment. Oikos 1981, 37, 257-264. [CrossRef]

26. Irshad, U.; Villenave, C.; Brauman, A.; Plassard, C. Grazing by nematodes on rhizosphere bacteria enhances nitrate and phosphorus availability to Pinus pinaster seedlings. Soil Biol. Biochem. 2011, 43, 2121-2126. [CrossRef]

27. Trap, J.; Ranoarisoa, P.M.; Irshad, U.; Plassard, C. Richness of rhizosphere organisms affects plant P nutrition according to P source and mobility. Agriculture 2021, 11, 157. [CrossRef]

28. Alphei, J.; Bonkowski, M.; Scheu, S. Protozoa, Nematoda and Lumbricidae in the rhizosphere of Hordelymus europeaus (Poaceae): Faunal interactions, response of microorganisms and effects on plant growth. Oecologia 1996, 106, 111-126. [CrossRef]

29. Djigal, D.; Brauman, A.; Diop, T.A.; Chotte, J.L.; Villenave, C. Influence of bacterial-feeding nematodes (Cephalobidae) on soil microbial communities during maize growth. Soil Biol. Biochem. 2004, 36, 323-331. [CrossRef] 
30. Bonkowski, M.; Clarholm, M. Stimulation of plant growth through interactions of bacteria and protozoa: Testing the auxiliary microbial loop hypothesis. Acta Protozool. 2012, 51, 237-247.

31. Liu, T.; Chen, X.; Hu, F.; Ran, W.; Shen, Q.; Li, H.; Whalen, J.K. Carbon-rich organic fertilizers to increase soil biodiversity: Evidence from a meta-analysis of nematode communities. Agric. Ecosyst. Environ. 2016, 232, 199-207. [CrossRef]

32. Trap, J.; Bernard, L.; Brauman, A.; Pablo, A.-L.; Plassard, C.; Ranoarisoa, M.P.; Blanchart, E. Plant roots increase bacterivorous nematode dispersion through nonuniform glass-bead media. J. Nematol. 2015, 47, 296. [PubMed]

33. Sánchez-Moreno, S.; Nicola, N.L.; Ferris, H.; Zalom, F.G. Effects of agricultural management on nematode-mite assemblages: Soil food web indices as predictors of mite community composition. Appl. Soil Ecol. 2009, 41, 107-117. [CrossRef]

34. Senapati, B. Biotic interactions between soil nematodes and earthworms. Soil Biol. Biochem. 1992, 24, 1441-1444. [CrossRef]

35. Yeates, G. Influence of earthworms on soil nematode populations. J. Nematol. 1980, 12, 242.

36. Sayre, R. Bacterial diseases of nematodes and their role in controlling nematode populations. Agric. Ecosyst. Environ. 1988, 24, 263-279. [CrossRef]

37. Raminoarison, M.; Razafimbelo, T.; Rakotoson, T.; Becquer, T.; Blanchart, E.; Trap, J. Multiple-nutrient limitation of upland rainfed rice in ferralsols: A greenhouse nutrient-omission trial. J. Plant Nutr. 2020, 43, 270-284. [CrossRef]

38. Trap, J.; Bonkowski, M.; Plassard, C.; Villenave, C.; Blanchart, E. Ecological importance of soil bacterivores for ecosystem functions. Plant Soil 2016, 398, 1-24. [CrossRef]

39. Walkley, A.; Black, I.A. An examination of the Degtjareff method for determining soil organic matter, and a proposed modification of the chromic acid titration method. Soil Sci. 1934, 37, 29-38. [CrossRef]

40. Kjeldahl, C. A new method for the determination of nitrogen in organic matter. Z. Anal. Chem. 1883, 22, 366. [CrossRef]

41. Sommers, L.; Nelson, D. Determination of total phosphorus in soils: A rapid perchloric acid digestion procedure. Soil Sci. Soc. Am. J. 1972, 36, 902-904. [CrossRef]

42. Amer, F.; Bouldin, D.; Black, C.; Duke, F. Characterization of soil phosphorus by anion exchange resin adsorption and P 32-equilibration. Plant Soil 1955, 6, 391-408. [CrossRef]

43. Rao, A.S.; Reddy, K.S.; Takkar, P. Malachite green method compared to ascorbic acid for estimating small amounts of phosphorus in water, $0.01 \mathrm{M}$ calcium chloride, and Olsen soil extracts. Commun. Soil Sci. Plant Anal. 1997, 28, 589-601. [CrossRef]

44. Seinhorst, J. Modifications of the elutriation method for extracting nematodes from soil. Nematologica 1962, 8, 117-128. [CrossRef]

45. Raboin, L.M.; Ramanantsoanirina, A.; Dzido, J.L.; Frouin, J.; Radanielina, T.; Tharreau, D.; Dusserre, J.; Ahmadi, N. Création variétale pour la riziculture pluviale d'altitude à Madagascar: Bilan de 25 années de sélection. Cah. Agric. 2013, 22, 450-458.

46. Raboin, L.M.; Randriambololona, T.; Radanielina, T.; Ramanantsoanirina, A.; Ahmadi, N.; Dusserre, J. Upland rice varieties for smallholder farming in the cold conditions in Madagascar's tropical highlands. Field Crop. Res. 2014, 169, 11-20. [CrossRef]

47. Villenave, C.; Rabary, B.; Chotte, J.L.; Blanchart, E.; Djigal, D. Impact of direct seeding mulch-based cropping systems on soil nematodes in a long-term experiment in Madagascar. Pesqui. Agropecu. Bras. 2009, 44, 949-953. [CrossRef]

48. Brookes, P.C.; Landman, A.; Pruden, G.; Jenkinson, D.S. Chloroform fumigation and the release of nitrogen: A rapid direct extraction method to measure microbial biomass nitrogen in soil. Soil Biol. Biochem. 1985, 17, 837-842. [CrossRef]

49. Paliy, O.; Shankar, V. Application of multivariate statistical techniques in microbial ecology. Mol. Ecol. 2016, 25, 1032-1057. [CrossRef] [PubMed]

50. Tenenhaus, M. La Régression PLS; Editions Technip: Paris, France, 1998; p. 254.

51. Wold, S.; Sjostrom, M.; Eriksson, L. PLS-regression: A basic tool of chemometrics. Chemom. Intell. Lab. Syst. 2001, 58, 109-130. [CrossRef]

52. Rakotomalala, R. TANAGRA: Un logiciel gratuit pour l'enseignement et la recherche. Actes De EGC RNTI-E3 2005, 2, 697-702.

53. Gérard, F. Clay minerals, iron/aluminum oxides, and their contribution to phosphate sorption in soils-A myth revisited. Geoderma 2016, 262, 213-226. [CrossRef]

54. Pardon, P.; Reubens, B.; Reheul, D.; Mertens, J.; De Frenne, P.; Coussement, T.; Janssens, P.; Verheyen, K. Trees increase soil organic carbon and nutrient availability in temperate agroforestry systems. Agric. Ecosyst. Environ. 2017, 247, 98-111. [CrossRef]

55. Ranoarisoa, M.P.; Blanchart, E.; Vom Brocke, K.; Ramanantsoanirina, A.; Sester, M.; Plassard, C.; Cournac, L.; Trap, J. Attractancy of bacterivorous nematodes to root-adhering soils differs according to rice cultivars. Rhizosphere 2017, 3, 128-131. [CrossRef]

56. Sundin, P.; Valeur, A.; Olsson, S.; Odham, G. Interactions between bacteria-feeding nematodes and bacteria in the rape rhizosphere-Effects on root exudation and distribution of bacteria. FEMS Microbiol. Ecol. 1990, 73, 13-22. [CrossRef]

57. Schachtman, D.P.; Reid, R.J.; Ayling, S.M. Phosphorus uptake by plants: From soil to cell. Plant Physiol. 1998, 116, 447-453. [CrossRef] [PubMed]

58. Ferris, H.; Venette, R.C.; Lau, S.S. Population energetics of bacterial-feeding nematodes: Carbon and nitrogen budgets. Soil Biol. Biochem. 1997, 29, 1183-1194. [CrossRef]

59. Hinsinger, P. Bioavailability of soil inorganic P in the rhizosphere as affected by root-induced chemical changes: A review. Plant Soil 2001, 237, 173-195. [CrossRef]

60. Calba, H.; Cazevieille, P.; Jaillard, B. Modelling of the dynamics of Al and protons in the rhizosphere of maize cultivated in acid substrate. Plant Soil 1999, 209, 57-69. [CrossRef]

61. Grzebisz, W.; Przygocka-Cyna, K.; Szczepaniak, W.; Diatta, J.; Potarzycki, J. Magnesium as a nutritional tool of nitrogen efficient management-plant production and environment. J. Elem. 2010, 15, 771-788. [CrossRef]

62. Ettema, C.H. Soil nematode diversity: Species coexistence and ecosystem function. J. Nematol. 1998, $30,159$. 
63. Jiang, Y.; Liu, M.; Zhang, J.; Chen, Y.; Chen, X.; Chen, L.; Li, H.; Zhang, X.X.; Sun, B. Nematode grazing promotes bacterial community dynamics in soil at the aggregate level. ISME J. 2017, 11, 2705-2717. [CrossRef] [PubMed]

64. Anderson, R.V.; Coleman, D.C. Population development and interactions between 2 species of bacteriophagic nematodes. Nematologica 1981, 27, 6-19. [CrossRef]

65. Noble, A.; Zenneck, I.; Randall, P. Leaf litter ash alkalinity and neutralisation of soil acidity. Plant Soil 1996, 179, $293-302$. [CrossRef] 